\title{
Analysis of Oral Pathogenic Microorganisms by Elderly's Systemic and Oral Health Status of the Elderly Over 65 Years
}

\author{
Min-Kyung Lee ${ }^{1, *}$, Su-Bin Yu ${ }^{2, *}$ and Hye-Jin Kim, ${ }^{1, * * *}$ \\ ${ }^{I}$ Department of Biomedical Health Science, Dong-eui University, Busan 47340, Korea \\ ${ }^{2}$ Department of Oral Anatomy, School of Dentistry, Pusan National University, Busan 50612, Korea
}

\begin{abstract}
Korean society is experiencing rapid growth due to industrialization and urbanization, and the aging of population is emerging. Degradation of the masticatory muscle due to aging and reduction of the number of mastications causes dry mouth syndrome with decreased saliva in the elderly. Changes in the amount and composition of saliva cause various oral diseases, especially, periodontal disease is closely related to the microorganisms that form the plaque. In the elderly education, stimulation saliva was collected at the first visit and the last visit to observe changes in microorganisms in the oral cavity. For the collection of the probes, the paraffin wax was chewed for 5 minutes. The samples were immediately refrigerated in a $50 \mathrm{cc}$ plastic tube and then stored at $-20^{\circ} \mathrm{C}$ until the next use. The subjects of this study were the elderly people aged 65 years or older, and the study was conducted on 16 persons, 3 males and 13 females. The distribution of saliva microorganisms according to rolling brushing method showed significant difference in all three groups (Aa \& Red complex, Orange complex and Green complex) before and after the education. In the group who answered that they had dentures, it was confirmed that the amount of microorganisms before and after education was significantly reduced in all three groups. There was a significant decrease in the amount of microorganisms in the Aa \& Red complex and Orange complex group in the case of hypertension related to systemic disease. In conclusion, the higher the interest of oral health and general health of the subjects, the more effective the education.
\end{abstract}

Key Words: Aged, Microbial, Periodontitis

\section{서 론}

한국사회는 산업화 및 도시화로 급격한 성장을 이루고 있으며, 그에 따른 여러 사회인구문제가 대두되고 있다. 여성의 사회진출증가 및 사회적 지위 상승으로 출산율 이 해마다 감소하고 있으며, 그 결과 우리 사회는 2017년 65 세 이상의 노인인구가 차지하는 비율이 약 $14 \%$ 에 달하 는 고령화 사회로 진입하였다(Cho, 2017). 또한 의료기술 의 발전으로 인간의 기대수명이 증가하였고, 노년 삶의
질을 결정짓는 건강에 대한 관심과 욕구는 점점 증가하고 있는 추세인 반면, 노인들은 젊은 연령층에 비해 건강관 련정보를 습득할 수 있는 기회가 많지 않으며 또한 여러 디지털 매체 이용능력도 부족하여 건강에 대한 욕구를 충 족할 수 있는 수단과 기회가 제한된다(Park, 2011). 이러한 이유들로 인해 노인복지프로그램 및 노인구강건강관리 프 로그램이 개발되고 있으나 가시적인 효과는 미미한 실정 이다.

인간은 노화현상에 따라 면역기능과 질병에 대한 회복 력이 젊은 연령층에 비해 현저하게 낮다. 따라서 노인층

Received: November 12, 2018 / Revised: December 10, 2018 / Accepted: December 11, 2018

*Professor.

† Corresponding author: Hye-Jin Kim. Department of Biomedical Health Science, Dong-eui University, 176 Eongwangno (gayadong san24), Busanjin-gu, Busan 47340, Korea.

Tel: +82-51-890-4237, Fax: +82-50501826878, e-mail: khj1126@deu.ac.kr

(C) The Korean Society for Biomedical Laboratory Sciences. All rights reserved.

(c) This is an Open Access article distributed under the terms of the Creative Commons Attribution Non-Commercial License (http://creativecommons.org/licenses/by-nc/3.0/) which permits unrestricted non-commercial use, distribution, and reproduction in any medium, provided the original work is properly cited. 
에서 발생할 수 있는 여러 대사성 및 퇴행성 병변은 전 신건강을 위협할 뿐만 아니라 구강조직의 변화도 초래 하며, 전신질환 치료제 복용과 저작근 퇴화 및 저작횟수 감소 등의 요인은 노인층에서 타액량이 감소하는 구강건 조증을 유발하게 되는데 그 비율이 약 $56 \%$ 로 보고된 바 있다(Yang et al., 2008; Joung and Cho, 2017). 타액량 감소 는 구강 내 자정작용을 감소시켜, 치아우식증 및 치주질 환의 유병률을 증가시키고, 미각장애, 구취를 유발한다 (Meyerowitz, 1991). 구강 내부는 습하고, 타액 내 풍부한 영양분으로 인하여 수많은 생리적 및 병적 미생물이 존재 하며, 타액량이나 조성의 변화는 미생물의 항상성을 파괴 하여 여러 구강질환을 유발한다(Roh and Kim, 2018). 특히 장년층부터 노년층까지 다발하는 구강상병인 치주질환은 구강 내 병원성 미생물이 군락을 이룬 치면세균막에 의해 서 발병되며, 치주질환 유발균이 심혈관질환과 류마티스 관절염 등의 여러 전신질환의 위험인자로 밝혀진 바 있 다(Lim et al., 2004; Choi and Cho, 2015). 선행연구(Lee et al., 2008)에서는 치주질환 유발균 중 가장 중요한 균주인 Porphyromonas gingivalis 가 사람 대동맥 평활근으로 침범 가능한 것을 밝혀냈다. 위의 근거들로 노화현상으로 인한 전신건강의 변화는 구강건강과 불가분의 관계에 있다고 볼 수 있으며, 구강위생관리는 건강의 척도로 여겨질 만 큼 중요성을 가진다. 노인의 전신건강은 곧 구강건강과 연관이 있고 구강건강 조건이 전신건강을 유지할 수 있는 척도가 될 수 있다.

따라서 본 연구는 구강건강관련 정보 습득 경로가 상대 적으로 어렵고, 구강병에 취약할 가능성이 높은 65 세 이 상 노인을 대상으로 구강건강관리 교육 후 타액과 미생물 수 변화를 조사하고, 특히 노인의 전신 및 구강건강상태 와 타액의 변화, 구강 내 미생물 분포 변화와의 관련성을 파악하여 추후 노인구강건강증진을 위한 기초자료를 제공 하고자 한다.

\section{연구대상 및 방법}

\section{연구대상}

본 연구는 부산시에 거주하며 연구의 취지와 목적을 이 해하고 설문에 동의를 얻은 65 세 이상 노인 20명을 대상 으로 2018년 3월 14일부터 동년 4월 24일까지 연구를 수 행하였으며 전신질환으로 건강에 문제가 있는 경우를 제 외하고 자의적으로 방문하여 4 주 교육을 모두 받은 16 명 을 최종 연구 대상자로 하였다.

\section{연구방법}

설문조사: 일반적 특성과 구강건강관리행태, 주관적으로 판단하는 구강상태, 전신질환에 대한 내용으로 설문조사 를 실시하였으며 노인을 대상으로 한 구강보건교육은 매 주 1 회 총 4 회 방문하여 반복 교육을 실시하였다. 교육내 용은 노인구강질환(치주병, 구취, 구강과 전신질환)과 틀 니관리법이다.

구강 내 미생물 검사: 노인 교육 시 첫 방문과 마지막 방 문에 자극성 타액을 채취하여 구강 내 미생물 변화를 관 찰하였다. 검채 채취는 5 분 동안 파라핀 왁스를 씹게 하 여 $50 \mathrm{cc}$ 플라스틱 튜브에 자극성 타액을 받아 즉시 냉장 보관 하였고, 유전자검사기관에 보낸 후 다음 사용 시까 지 $-20{ }^{\circ} \mathrm{C}$ 에서 보관되었다.

Real-time PCR에 의한 정량분석: NEXprep ${ }^{\mathrm{TM}}$ Cell/Tissue Genomic DNA kit를 이용하여 제조사의 지시에 따라 geno$\operatorname{mic} \mathrm{DNA}$ 를 추출하였다. 구강미생물의 정량분석을 위하여 PerioGen ${ }^{\mathrm{TM}}$ Perio Real-Time PCR Kit (Microis, Korea)를 이용 하였다. 구강 내 존재하는 전체 미생물의 검출을 위해서 는 $16 \mathrm{~s} \mathrm{rDNA}$ 단편을 증폭하였고, 각각의 미생물 검출을 위해서는 functional gene (rgp, waa, gtf)으로부터 specific primer를 제작하여 약 $200 \mathrm{bp}$ 내외의 DNA 단편을 각각 증폭하였다. Multiplex real-time PCR에 사용된 probe들은 서로 간섭을 고려하여 파장이 겹치지 않는 3종(FAM, Cy5, $\mathrm{HEX})$ 을 선택하였고, 각 반응에서 분석대상 균종들 중 3종 씩 묶어서 네 종류의 panel으로 구성하였고 Table 1에 나 타내었다. Real-time PCR 반응 용액은 추출한 total DNA $2 \mu \mathrm{L}$ 를 각각의 primer set $10 \mathrm{pmol}$, probe와 완충용액, 1 unit Hot-start Taq DNA polymerase (GeneAll, Korea)을 혼합하 여 총 $20 \mu \mathrm{L}$ 가 되도록 제조하였다. 96 well에 분주 후 $\mathrm{ABI}$ 7500 Fast Real-Time PCR System (Applied Biosystems, Life Technologies, Carlsbad, CA, USA)을 이용하여 정량분석을 시행하였다.

구강 내 미생물 분류: 치주질환을 일으키는 원인 세균들 의 특징, 상호 연관성, 염색반응, 집락의 형태 및 색소의 생성 유무 및 임상적 지표 등을 기준으로 Red complex, Orange complex, Green complex, Yellow complex, Purple complex의 5 개 색깔 별로 분류하나(Socransky et al., 1998) 본 연구에서는 Red complex, Orange complex, Green complex 
3 개의 군으로만 분류하였다. 치주질환과 관련성이 있는 치 은연하의 세균 중 P. gingivalis, T. forsythia, T. denticola를 Red complex라 하였으며, 이 complex는 치주낭 깊이와 탐 침 시 출혈과 같은 치주질환 지표와 강한 상관관계를 가 진다고 보고하였다(Socransky et al., 1998). 치주질환과 관련 이 깊은 Orange complex에는 P. intermedia, F. nucleaum, $P$. micra, C. rectun으로 분류된다. Green complex는 초기에 집 락을 이루는 군으로 A. actinomycetemcomitans, E. corrodens 로 분류되고 있으며, Orange complex와 관련이 있는 것으 로 밝혀졌다.

\section{분석방법}

수집한 자료를 이용하여 SPSS statistics v. 23을 이용하여 결과분석 하였다. 성별, 연령은 빈도와 백분율을 제시하였 고, 성별에 따른 구강미생물 분포는 사전 검사 동질성 검 증(독립표본 $t$ 검증)을 통해 확인하였다. 건강관리행태, 구 강상태, 전신질환 유무에서 구강건강관리 교육 전과 후에 따른 구강 내 미생물 분포는 Wilcoxon's signed rank test를 실시하였으며 건강관리행태, 구강상태, 전신질환과의 관련 성을 파악하기 위해 Correlation analysis는 Spearman 순위

Table 1. The bacteria strains used in this study

\begin{tabular}{|c|c|}
\hline Division & Target strain \\
\hline \multirow{3}{*}{ A Panel } & $\begin{array}{l}\text { Aggregatibacter actinomycetemcomitans } \\
\text { KCTC } 3698\end{array}$ \\
\hline & Porphyromonas gingivalis KCTC 5352 \\
\hline & Tannerella forsythia KCTC 5666 \\
\hline \multirow{3}{*}{ B Panel } & Treponema denticola KCTC 15104 \\
\hline & Prevotella intermedia KCTC 5692 \\
\hline & Fusobacterium nucleatum KCTC 2640 \\
\hline \multirow{3}{*}{ C Panel } & Parvimonas micra ATCC 33270 \\
\hline & Campylobacter rectus KCTC 5636 \\
\hline & Eikenella corrodens KCTC 15198 \\
\hline \multirow{3}{*}{ D Panel } & Eubacterium codatum KCTC 15015 \\
\hline & Prevotella nigrescens KCTC 5690 \\
\hline & Total bacteria 16s rDNA control \\
\hline
\end{tabular}

상관분석을 실시하였다.

\section{결 과}

\section{연구 대상자의 성별에 따른 연령 분포}

본 연구 대상자의 성별에 따른 연령 분포를 Table 2에 나타내었다. 연구대상은 65 세 이상의 노인 연령층이고, 남자 3명, 여자 13명으로 총 16 명을 대상으로 연구를 시 행하였다. 그 중 80세 이하 노인비율이 $50 \%, 81 \sim 85$ 세 노인비율이 $37.5 \%, 86$ 세 이상 노인의 비율은 $12.5 \%$ 였다. Table 3은 성별에 따른 구강미생물 분포의 사전 동질성을 검사한 결과 Aa \& Red complex는 남자가 6.07, 여자가 8.52 , Orange complex는 남자가 18.00 , 여자가 21.42, Green complex는 남자가 4.01, 여자가 3.88로 성별에 따라 세 그 룹이 통계적으로 차이가 없는 것으로 동질하다고 해석하 였다.

\section{연구 대상자의 구강건강관리행태에 따른 타액 내 미생 물 분포}

Table 4는 대상자의 구강건강관리행태 따른 타액 내 미 생물 분포 결과를 나타내었다. 구강건강관리행태는 칫솔 질 방법, 칫솔질 횟수, 혀 닦기 유무에 대하여 설문하였다. 타액 내 미생물은 치주질환 위험 기여도에 따라 세 그룹 으로 나누었고, 구강보건교육 전, 후 미생물의 총량에 차 이가 있는지를 조사하였다. 칫솔질 방법에 따른 타액 미 생물 분포 량 조사 결과 회전법사용과 Orange complex $(P=0.019)$ 그룹 간 교육 전, 후 유의한 차이가 있었으며, 아무렇게나 칫솔질을 하는 경우에서는 Aa \& Red complex $(P=0.005)$, Orange complex $(P=0.007)$ 에서 교육 전, 후 유

Table 2. Distrubution of gender and age

\begin{tabular}{lcccr}
\hline \hline Group & $\sim 80$ & $81 \sim 85$ & $86 \sim$ & Total \\
\hline Male & $1(33.3)$ & $1(33.3)$ & $1(33.3)$ & $3(100.0)$ \\
Female & $7(53.8)$ & $5(38.5)$ & $1(7.7)$ & $13(100.0)$ \\
\hline Total & $8(50.0)$ & $6(37.5)$ & $2(12.5)$ & $16(100.0)$ \\
\hline
\end{tabular}

Table 3. Pre- equivalence check of oral microorganisms distribution by gender

\begin{tabular}{lcccccc}
\hline \hline \multicolumn{1}{c}{ Group } & Aa \& Red complex & $t(P)$ & Orange complex & $t(P)$ & Green complex & $t(P)$ \\
\hline Male & $6.07 \pm 3.73$ & -1.227 & $18.00 \pm 6.59$ & -1.219 & $4.01 \pm .58$ & .112 \\
Female & $8.52 \pm 3.31$ & $(.240)$ & $21.42 \pm 4.94$ & $(.243)$ & $3.88 \pm 1.80$ & $(.912)$ \\
\hline
\end{tabular}


Table 4. Distribution of oral microorganisms according to oral health management behavior

\begin{tabular}{|c|c|c|c|c|c|c|c|c|c|c|}
\hline \multirow{2}{*}{\multicolumn{2}{|c|}{ Division }} & \multicolumn{3}{|c|}{ Aa \& Red complex } & \multicolumn{3}{|c|}{ Orange complex } & \multicolumn{3}{|c|}{ Green complex } \\
\hline & & Pre-edu & Post-edu & $\mathrm{Z}(P)$ & Pre-edu & Post-edu & $\mathrm{Z}(P)$ & Pre-edu & Post-edu & $\mathrm{Z}(P)$ \\
\hline \multirow{3}{*}{$\begin{array}{l}\text { Methods of } \\
\text { toothbrushing }\end{array}$} & $\begin{array}{l}\text { Rolling } \\
\text { methods }\end{array}$ & $\begin{array}{l}14.52 \\
\pm 3.43\end{array}$ & $\begin{array}{c}5.15 \\
\pm 2.16\end{array}$ & $\begin{array}{l}-1.604 \\
(.109)\end{array}$ & $\begin{array}{l}24.51 \\
\pm 4.85\end{array}$ & $\begin{array}{l}15.53 \\
\pm 4.36\end{array}$ & $\begin{array}{l}-1.604 \\
(.019)\end{array}$ & $\begin{array}{c}5.69 \\
\pm 0.12\end{array}$ & $\begin{array}{c}4.55 \\
\pm 0.47\end{array}$ & $\begin{array}{l}-1.604 \\
(.109)\end{array}$ \\
\hline & $\begin{array}{l}\text { Vertical + } \\
\text { Horizontal }\end{array}$ & $\begin{array}{l}12.12 \\
\pm 3.88\end{array}$ & $\begin{array}{c}8.91 \\
\pm 4.31\end{array}$ & $\begin{array}{l}-.535 \\
(.593)\end{array}$ & $\begin{array}{l}25.82 \\
\pm 8.26\end{array}$ & $\begin{array}{l}24.20 \\
\pm 0.52\end{array}$ & $\begin{array}{c}.000 \\
(1.000)\end{array}$ & $\begin{array}{c}3.60 \\
\pm 3.14\end{array}$ & $\begin{array}{c}4.00 \\
\pm 0.74\end{array}$ & $\begin{array}{c}.000 \\
(1.000)\end{array}$ \\
\hline & $\begin{array}{l}\text { Do at } \\
\text { random }\end{array}$ & $\begin{array}{l}13.59 \\
\pm 1.80\end{array}$ & $\begin{array}{c}8.95 \\
\pm 3.25\end{array}$ & $\begin{array}{l}-2.803 \\
(.005)\end{array}$ & $\begin{array}{l}25.50 \\
\pm 5.05\end{array}$ & $\begin{array}{l}21.37 \\
\pm 3.99\end{array}$ & $\begin{array}{l}-2.701 \\
(.007)\end{array}$ & $\begin{array}{c}4.22 \\
\pm 1.79\end{array}$ & $\begin{array}{c}3.69 \\
\pm 2.01\end{array}$ & $\begin{array}{l}-1.481 \\
(.139)\end{array}$ \\
\hline \multirow{3}{*}{$\begin{array}{l}\text { Frequency of } \\
\text { toothbrushing }\end{array}$} & $\sim 2$ times & $\begin{array}{l}16.37 \\
\pm 2.77\end{array}$ & $\begin{array}{c}8.22 \\
\pm 0.90\end{array}$ & $\begin{array}{l}-1.342 \\
(.180)\end{array}$ & $\begin{array}{l}27.79 \\
\pm 2.27\end{array}$ & $\begin{array}{l}20.07 \\
\pm 5.23\end{array}$ & $\begin{array}{l}-1.342 \\
(.180)\end{array}$ & $\begin{array}{c}4.5 \\
\pm 1.78\end{array}$ & $\begin{array}{c}5.08 \\
\pm 0.09\end{array}$ & $\begin{array}{l}-.447 \\
(.655)\end{array}$ \\
\hline & 3 times & $\begin{array}{l}12.92 \\
\pm 2.39\end{array}$ & $\begin{array}{c}8.10 \\
\pm 3.47\end{array}$ & $\begin{array}{l}-2.824 \\
(.005)\end{array}$ & $\begin{array}{l}24.66 \\
\pm 5.91\end{array}$ & $\begin{array}{l}21.06 \\
\pm 4.97\end{array}$ & $\begin{array}{l}-2.197 \\
(.028)\end{array}$ & $\begin{array}{c}4.12 \\
\pm 2.08\end{array}$ & $\begin{array}{c}3.61 \\
\pm 1.78\end{array}$ & $\begin{array}{l}-1.778 \\
(.075)\end{array}$ \\
\hline & 4 times & $\begin{array}{l}14.00 \\
\pm 0.60\end{array}$ & $\begin{array}{c}9.00 \\
\pm 6.48\end{array}$ & $\begin{array}{l}-1.342 \\
(.180)\end{array}$ & $\begin{array}{l}27.26 \\
\pm 1.48\end{array}$ & $\begin{array}{l}20.00 \\
\pm 0.82\end{array}$ & $\begin{array}{l}-1.342 \\
(.180)\end{array}$ & $\begin{array}{c}5.77 \\
\pm 0.04\end{array}$ & $\begin{array}{c}4.54 \\
\pm 0.02\end{array}$ & $\begin{array}{r}-1.342 \\
(.180)\end{array}$ \\
\hline \multirow{2}{*}{$\begin{array}{l}\text { Tongue } \\
\text { brushing }\end{array}$} & Yes & $\begin{array}{l}13.90 \\
\pm 2.21\end{array}$ & $\begin{array}{c}7.86 \\
\pm 3.34\end{array}$ & $\begin{array}{l}-3.059 \\
(.002)\end{array}$ & $\begin{array}{l}25.30 \\
\pm 5.12\end{array}$ & $\begin{array}{l}19.96 \\
\pm 4.84\end{array}$ & $\begin{array}{l}-2.981 \\
(.003)\end{array}$ & $\begin{array}{c}4.54 \\
\pm 1.75\end{array}$ & $\begin{array}{c}3.90 \\
\pm 1.88\end{array}$ & $\begin{array}{r}-1.867 \\
(.062)\end{array}$ \\
\hline & No & $\begin{array}{l}12.26 \\
\pm 3.15\end{array}$ & $\begin{array}{c}9.33 \\
\pm 3.95\end{array}$ & $\begin{array}{l}-1.095 \\
(.273)\end{array}$ & $\begin{array}{l}25.61 \\
\pm 6.51\end{array}$ & $\begin{array}{l}23.32 \\
\pm 1.89\end{array}$ & $\begin{array}{l}-.365 \\
(.715)\end{array}$ & $\begin{array}{c}3.89 \\
\pm 2.63\end{array}$ & $\begin{array}{c}3.93 \\
\pm 0.47\end{array}$ & $\begin{array}{l}-.368 \\
(.713)\end{array}$ \\
\hline
\end{tabular}

Table 5. Distribution of oral microorganisms according to oral health status

\begin{tabular}{|c|c|c|c|c|c|c|c|c|c|c|}
\hline \multirow{2}{*}{\multicolumn{2}{|c|}{ Division }} & \multicolumn{3}{|c|}{ Aa \& Red complex } & \multicolumn{3}{|c|}{ Orange complex } & \multicolumn{3}{|c|}{ Green complex } \\
\hline & & Pre-edu & Post-edu & $\mathrm{Z}(P)$ & Pre-edu & Post-edu & $\mathrm{Z}(P)$ & Pre-edu & Post-edu & $\mathrm{Z}(P)$ \\
\hline \multirow{2}{*}{ Denture } & Yes & $\begin{array}{l}13.11 \\
\pm 2.88\end{array}$ & $\begin{array}{c}7.94 \\
\pm 3.67\end{array}$ & $\begin{array}{c}-2.240 \\
(.025)\end{array}$ & $\begin{array}{l}26.14 \\
\pm 5.61\end{array}$ & $\begin{array}{l}22.05 \\
\pm 3.50\end{array}$ & $\begin{array}{c}-1.680 \\
(.093)\end{array}$ & $\begin{array}{c}3.50 \\
\pm 2.45\end{array}$ & $\begin{array}{c}3.16 \\
\pm 2.02\end{array}$ & $\begin{array}{c}-.339 \\
(.735)\end{array}$ \\
\hline & No & $\begin{array}{l}13.86 \\
\pm 2.12\end{array}$ & $\begin{array}{c}8.51 \\
\pm 3.40\end{array}$ & $\begin{array}{l}-2.521 \\
(.012)\end{array}$ & $\begin{array}{l}24.61 \\
\pm 5.15\end{array}$ & $\begin{array}{r}19.55 \\
\pm 5.23\end{array}$ & $\begin{array}{l}-2.380 \\
(.017)\end{array}$ & $\begin{array}{c}5.25 \\
\pm 0.46\end{array}$ & $\begin{array}{c}4.66 \\
\pm 0.53\end{array}$ & $\begin{array}{c}-2.240 \\
(.025)\end{array}$ \\
\hline \multirow{2}{*}{ Halitosis } & Yes & $\begin{array}{l}13.58 \\
\pm 0.79\end{array}$ & $\begin{array}{c}9.76 \\
\pm 1.95\end{array}$ & $\begin{array}{c}-1.342 \\
(.180)\end{array}$ & $\begin{array}{l}23.38 \\
\pm 7.94\end{array}$ & $\begin{array}{l}21.39 \\
\pm 4.62\end{array}$ & $\begin{array}{l}-.447 \\
(.655)\end{array}$ & $\begin{array}{c}5.20 \\
\pm 0.07\end{array}$ & $\begin{array}{c}5.01 \\
\pm 0.42\end{array}$ & $\begin{array}{c}-.447 \\
(.655)\end{array}$ \\
\hline & No & $\begin{array}{r}13.47 \\
\pm 2.65 \\
\end{array}$ & $\begin{array}{c}8.01 \\
\pm 3.59 \\
\end{array}$ & $\begin{array}{l}-3.045 \\
(.002)\end{array}$ & $\begin{array}{l}25.66 \\
\pm 5.14\end{array}$ & $\begin{array}{l}20.72 \\
\pm 4.64\end{array}$ & $\begin{array}{c}-2.668 \\
(.008)\end{array}$ & $\begin{array}{c}4.26 \\
\pm 2.04 \\
\end{array}$ & $\begin{array}{c}3.75 \\
\pm 1.68 \\
\end{array}$ & $\begin{array}{r}-1.503 \\
(.133) \\
\end{array}$ \\
\hline \multirow{2}{*}{ Gum pain } & Yes & $\begin{array}{l}14.17 \\
\pm 1.62\end{array}$ & $\begin{array}{c}8.90 \\
\pm 3.80\end{array}$ & $\begin{array}{l}-1.826 \\
(.068)\end{array}$ & $\begin{array}{l}25.82 \\
\pm 5.65\end{array}$ & $\begin{array}{l}21.25 \\
\pm 2.80\end{array}$ & $\begin{array}{l}-1.461 \\
(.144)\end{array}$ & $\begin{array}{c}3.94 \\
\pm 2.66\end{array}$ & $\begin{array}{c}3.31 \\
\pm 2.22\end{array}$ & $\begin{array}{c}-1.604 \\
(.109)\end{array}$ \\
\hline & No & $\begin{array}{r}13.26 \\
\pm 2.72\end{array}$ & $\begin{array}{c}8.00 \\
\pm 3.45\end{array}$ & $\begin{array}{l}-2.824 \\
(.005)\end{array}$ & $\begin{array}{l}25.22 \\
\pm 5.38\end{array}$ & $\begin{array}{l}20.65 \\
\pm 5.03\end{array}$ & $\begin{array}{c}-2.353 \\
(.019)\end{array}$ & $\begin{array}{c}4.52 \\
\pm 1.74\end{array}$ & $\begin{array}{c}4.11 \\
\pm 1.44\end{array}$ & $\begin{array}{r}-1.177 \\
(.239)\end{array}$ \\
\hline \multirow{2}{*}{ Tooth pain } & Yes & $\begin{array}{l}14.08 \\
\pm 1.97\end{array}$ & $\begin{array}{c}7.34 \\
\pm 2.66\end{array}$ & $\begin{array}{l}-1.604 \\
(.109)\end{array}$ & $\begin{array}{l}25.70 \\
\pm 6.91\end{array}$ & $\begin{array}{l}21.48 \\
\pm 3.38\end{array}$ & $\begin{array}{r}-1.069 \\
(.285)\end{array}$ & $\begin{array}{c}3.33 \\
\pm 2.89\end{array}$ & $\begin{array}{c}2.91 \\
\pm 2.54\end{array}$ & $\begin{array}{r}-1.342 \\
(.180)\end{array}$ \\
\hline & No & $\begin{array}{l}13.35 \\
\pm 2.62\end{array}$ & $\begin{array}{c}8.43 \\
\pm 3.65\end{array}$ & $\begin{array}{l}-2.900 \\
(.004)\end{array}$ & $\begin{array}{l}25.30 \\
\pm 5.16\end{array}$ & $\begin{array}{l}20.65 \\
\pm 4.81\end{array}$ & $\begin{array}{l}-2.481 \\
(.013)\end{array}$ & $\begin{array}{c}4.62 \\
\pm 1.70\end{array}$ & $\begin{array}{c}4.14 \\
\pm 1.38\end{array}$ & $\begin{array}{r}-1.363 \\
(.173)\end{array}$ \\
\hline
\end{tabular}

의한 차이가 있었다. 1 일 칫솔질 빈도가 3 회라고 응답한 군에서는 Aa \& Red complex $(P=0.005)$, Orange complex $(P=0.028)$ 에서 교육 전, 후 유의한 차이가 있었으며, 혀를 닦는 그룹에서도 Aa \& Red complex ( $P=0.002)$, Orange com$\operatorname{plex}(P=0.003)$ 에서 교육 전, 후 차이를 보였다.

\section{연구 대상자의 구강상태에 따른 타액 내 미생물 분포}

Table 5는 대상자의 구강상태에 따른 타액 내 미생물 분포 결과를 나타내었다. 구강상태는 의치장착 유무, 구취 유무, 잇몸통증 유무, 치아통증 유무로 구분하였다. 의치 를 장착한다는 응답군에서 Aa \& Red complex 그룹의 교육 
Table 6. Distribution of oral microorganisms according to systemic disease

\begin{tabular}{|c|c|c|c|c|c|c|c|c|c|c|}
\hline \multirow{2}{*}{\multicolumn{2}{|c|}{ Division }} & \multicolumn{3}{|c|}{ Aa \& Red complex } & \multicolumn{3}{|c|}{ Orange complex } & \multicolumn{3}{|c|}{ Green complex } \\
\hline & & Pre-edu & Post-edu & $\mathrm{Z}(P)$ & Pre-edu & Post-edu & $\mathrm{Z}(P)$ & Pre-edu & Post-edu & $\mathrm{Z}(P)$ \\
\hline \multirow{2}{*}{ Hypertension } & Yes & $\begin{array}{l}13.86 \\
\pm 3.33\end{array}$ & $\begin{array}{c}7.92 \\
\pm 3.33\end{array}$ & $\begin{array}{l}-2.366 \\
(.018)\end{array}$ & $\begin{array}{l}25.48 \\
\pm 4.81\end{array}$ & $\begin{array}{l}19.58 \\
\pm 3.86\end{array}$ & $\begin{array}{r}-2.366 \\
(.018)\end{array}$ & $\begin{array}{l}5.12 \\
\pm .93\end{array}$ & $\begin{array}{l}4.68 \\
\pm .53\end{array}$ & $\begin{array}{l}-1.183 \\
(.237)\end{array}$ \\
\hline & No & $\begin{array}{l}13.20 \\
\pm 2.46\end{array}$ & $\begin{array}{c}8.47 \\
\pm 3.69\end{array}$ & $\begin{array}{l}-2.429 \\
(.015)\end{array}$ & $\begin{array}{l}25.29 \\
\pm 5.88\end{array}$ & $\begin{array}{l}21.76 \\
\pm 4.93\end{array}$ & $\begin{array}{l}-1.718 \\
(.086)\end{array}$ & $\begin{array}{l}25.29 \\
\pm 5.88\end{array}$ & $\begin{array}{l}21.76 \\
\pm 4.93\end{array}$ & $\begin{array}{r}-1.262 \\
(.207)\end{array}$ \\
\hline \multirow{2}{*}{ Osteoporosis } & Yes & $\begin{array}{l}15.01 \\
\pm 5.16\end{array}$ & $\begin{array}{c}7.89 \\
\pm 3.09\end{array}$ & $\begin{array}{l}-1.826 \\
(.068)\end{array}$ & $\begin{array}{l}25.99 \\
\pm 5.83\end{array}$ & $\begin{array}{l}21.50 \\
\pm 2.31\end{array}$ & $\begin{array}{l}-1.461 \\
(.144)\end{array}$ & $\begin{array}{c}4.68 \\
\pm 1.38\end{array}$ & $\begin{array}{c}3.37 \\
\pm 2.31\end{array}$ & $\begin{array}{r}-1.826 \\
(.068)\end{array}$ \\
\hline & No & $\begin{array}{l}12.98 \\
\pm 2.40\end{array}$ & $\begin{array}{c}8.34 \\
\pm 3.66\end{array}$ & $\begin{array}{l}-2.746 \\
(.006)\end{array}$ & $\begin{array}{l}25.17 \\
\pm 5.32\end{array}$ & $\begin{array}{l}20.57 \\
\pm 4.47\end{array}$ & $\begin{array}{l}-2.353 \\
(.019)\end{array}$ & $\begin{array}{c}4.27 \\
\pm 2.12\end{array}$ & $\begin{array}{c}4.09 \\
\pm 1.41\end{array}$ & $\begin{array}{l}-.889 \\
(.374)\end{array}$ \\
\hline \multirow{2}{*}{$\begin{array}{l}\text { Cardiovascular } \\
\text { disease }\end{array}$} & Yes & $\begin{array}{l}11.93 \\
\pm 3.75\end{array}$ & $\begin{array}{c}8.78 \\
\pm 3.83\end{array}$ & $\begin{array}{l}-1.069 \\
(.285)\end{array}$ & $\begin{array}{l}24.57 \\
\pm 2.36\end{array}$ & $\begin{array}{l}23.56 \\
\pm 7.15\end{array}$ & $\begin{array}{l}-.535 \\
(.593)\end{array}$ & $\begin{array}{l}2.80 \\
\pm .87\end{array}$ & $\begin{array}{l}2.65 \\
\pm .36\end{array}$ & $\begin{array}{c}.000 \\
(1.000)\end{array}$ \\
\hline & No & $\begin{array}{l}13.85 \\
\pm 2.13\end{array}$ & $\begin{array}{c}8.10 \\
\pm 3.49\end{array}$ & $\begin{array}{l}-3.180 \\
(.001)\end{array}$ & $\begin{array}{l}25.57 \\
\pm 1.37\end{array}$ & $\begin{array}{l}20.17 \\
\pm 4.49\end{array}$ & $\begin{array}{l}-3.110 \\
(.002)\end{array}$ & $\begin{array}{c}4.74 \\
\pm 1.58\end{array}$ & $\begin{array}{c}4.20 \\
\pm 1.37\end{array}$ & $\begin{array}{r}-1.962 \\
(.050)\end{array}$ \\
\hline \multirow{2}{*}{$\begin{array}{l}\text { Gastrointestinal } \\
\text { disorder }\end{array}$} & Yes & $\begin{array}{l}14.18 \\
\pm 1.86\end{array}$ & $\begin{array}{c}6.47 \\
\pm 4.74\end{array}$ & $\begin{array}{l}-1.826 \\
(.068)\end{array}$ & $\begin{array}{l}26.64 \\
\pm 5.54\end{array}$ & $\begin{array}{l}20.35 \\
\pm 3.65\end{array}$ & $\begin{array}{l}-1.826 \\
(.068)\end{array}$ & $\begin{array}{c}3.83 \\
\pm 2.61\end{array}$ & $\begin{array}{c}3.09 \\
\pm 2.08\end{array}$ & $\begin{array}{l}-1.633 \\
(.102)\end{array}$ \\
\hline & No & $\begin{array}{l}13.26 \\
\pm 2.68\end{array}$ & $\begin{array}{c}8.81 \\
\pm 2.91\end{array}$ & $\begin{array}{l}-2.824 \\
(.005)\end{array}$ & $\begin{array}{l}24.95 \\
\pm 5.35\end{array}$ & $\begin{array}{l}20.95 \\
\pm 4.88\end{array}$ & $\begin{array}{l}-2.275 \\
(.023)\end{array}$ & $\begin{array}{c}4.56 \\
\pm 1.75\end{array}$ & $\begin{array}{c}4.18 \\
\pm 1.44\end{array}$ & $\begin{array}{l}-1.177 \\
(.239)\end{array}$ \\
\hline
\end{tabular}

전, 후 미생물의 양이 유의하게 줄어든 것을 확인하였으 며 $(P=0.025)$, 의치를 장착하지 않은 그룹에서는 세 그룹 모두에서 미생물양이 유의하게 감소하는 것이 확인되었 다 $(P=0.012, P=0.017, P=0.025)$. 구취가 없다고 응답한 경 우 Aa \& Red complex와 Orange complex 그룹에서만 유의 한 차이가 있었다 $(P=0.002, P=0.008)$. 또한 잇몸통증과 치아통증에서 통증이 없다고 응답한 경우에서 $\mathrm{Aa} \& \mathrm{Red}$ complex, Orange complex 미생물의 양의 유의한 감소를 확 인할 수 있었다 $(P=0.005, P=0.019),(P=0.004, P=0.013)$.

\section{연구 대상자의 전신질환 유무에 따른 타액 내 미생물 분포}

Table 6은 대상자의 전신건강상태에 따른 타액 내 미생 물 분포 결과를 나타내었다. 전신질환 유무에서 고혈압, 골다공증, 심혈관계질환, 위장장애 등의 질환을 않고 있는 지에 따라 각 미생물 분포 량이 교육 전, 후 어떠한 차이 를 보이는지 확인하였다. 그 결과, 고혈압 유무에서는 고 혈압을 않고 있는 경우에서 Aa \& Red complex와 Orange complex 그룹의 미생물 양이 유의하게 감소하는 것을 확 인하였고 $(P=0.018, P=0.018)$, 고혈압을 않지 않는 군에서 는 Aa \& Red complex만 유의하게 감소하였다 $(P=0.015)$. 골다공증은 이환되어 있지 않다고 응답한 군에서 $\mathrm{Aa} \&$ Red complex와 Orange complex 그룹의 미생물 양이 유의 하게 감소되는 것이 확인되었으며 $(P=0.006, P=0.019)$, 심
혈관계질환 유무에서는 질환이 없다고 응답한 군에서 세 그룹 모두 유의한 차이가 있었다 $(P=0.001, P=0.002, P=$ 0.050). 위장장애 유무에서 위장장애가 없는 경우 $\mathrm{Aa} \&$ Red complex와 Orange complex 그룹에서 유의한 차이가 있었다 $P=0.005, P=0.023)$.

\section{전신건강 및 구강건강상태, 구강 내 미생물과의 관련성}

Table 7은 전신건강관리 교육 전과 후의 구강 내 미생 물 총량, 칫솔질 행태, 구강건강상태, 전신건강상태와의 상관관계를 분석한 결과이다. 교육 전 미생물의 총량과 유의한 음의 상관관계를 가지는 요인으로는 1 일 칫솔질 빈도 $(r=-.680, P=0.004)$, 위장장애 $(r=-.519, P=0.040)$ 가 있었 고, 교육 전 미생물의 양은 의치장착 유무와는 유의한 양 의 상관관계를 가지는 것으로 확인되었다 $(r=.550, P=0.027)$. 또한 잇몸통증과 고혈압이 $(r=-.509, P=0.044)$ 유의한 양의 상관관계를 가졌다.

\section{고 찰}

본 연구는 65 세 이상 노인 연령층을 대상으로 노인구 강질환관리 및 틀니관리법에 대한 구강보건교육 수행 전, 후에 각각 채취한 타액 내 미생물 양의 변화를 확인하고, 미생물 변화가 어떠한 전신 및 구강건강 특성과 관련 있 는지 확인하고자 수행하였다. 본 연구에서 조사한 요인은 
Table 7. The relationship between general health and oral health

\begin{tabular}{|c|c|c|c|c|c|c|c|c|c|c|c|c|}
\hline Division $^{*}$ & 1 & 2 & 3 & 4 & 5 & 6 & 7 & 8 & 9 & 10 & 11 & 12 \\
\hline $\begin{array}{l}\text { Amount of } \\
\text { microorganism (pre) }\end{array}$ & 1 & & & & & & & & & & & \\
\hline $\begin{array}{l}\text { Amount of } \\
\text { microorganism (post) }\end{array}$ & $\begin{array}{l}-.337 \\
(.202)\end{array}$ & 1 & & & & & & & & & & \\
\hline $\begin{array}{l}\text { Frequncy of } \\
\text { toothbrushing }\end{array}$ & $\begin{array}{l}-.680 \\
(.004)\end{array}$ & $\begin{array}{l}.339 \\
(.198)\end{array}$ & 1 & & & & & & & & & \\
\hline $\begin{array}{l}\text { Methods of } \\
\text { toothbrushing }\end{array}$ & $\begin{array}{l}.120 \\
(.659)\end{array}$ & $\begin{array}{l}-.143 \\
(.597)\end{array}$ & $\begin{array}{l}.971 \\
(.097)\end{array}$ & 1 & & & & & & & & \\
\hline Halitosis & $\begin{array}{l}.288 \\
(.279)\end{array}$ & $\begin{array}{l}-.062 \\
(.821)\end{array}$ & $\begin{array}{l}.971 \\
(.097)\end{array}$ & $\begin{array}{l}.285 \\
(.278)\end{array}$ & 1 & & & & & & & \\
\hline Gum pain & $\begin{array}{l}-.314 \\
(.236)\end{array}$ & $\begin{array}{l}-.157 \\
(.562)\end{array}$ & $\begin{array}{l}.289 \\
(.278)\end{array}$ & $\begin{array}{l}.435 \\
(.092)\end{array}$ & $\begin{array}{l}.218 \\
(.417)\end{array}$ & 1 & & & & & & \\
\hline Tooth pain & $\begin{array}{l}-.157 \\
(.562)\end{array}$ & $\begin{array}{l}-.209 \\
(.438)\end{array}$ & $\begin{array}{l}.971 \\
(.097)\end{array}$ & $\begin{array}{l}.362 \\
(.168)\end{array}$ & $\begin{array}{l}.303 \\
(.255)\end{array}$ & $\begin{array}{l}.832 \\
(.001)\end{array}$ & 1 & & & & & \\
\hline Denture & $\begin{array}{c}.550 \\
(.027)\end{array}$ & $\begin{array}{c}-.196 \\
(.467)\end{array}$ & $\begin{array}{c}-.249 \\
(.352)\end{array}$ & $\begin{array}{c}-.015 \\
(.957)\end{array}$ & $\begin{array}{c}.355 \\
(.178)\end{array}$ & $\begin{array}{c}.135 \\
(.617)\end{array}$ & $\begin{array}{c}.225 \\
(.402)\end{array}$ & 1 & & & & \\
\hline Hypertension & $\begin{array}{l}.343 \\
(.194)\end{array}$ & $\begin{array}{l}.012 \\
(.098)\end{array}$ & $\begin{array}{l}-.252 \\
(.346)\end{array}$ & $\begin{array}{l}-.142 \\
(.599)\end{array}$ & $\begin{array}{l}-.333 \\
(.207)\end{array}$ & $\begin{array}{l}-.509 \\
(.044)\end{array}$ & $\begin{array}{l}-.424 \\
(.102)\end{array}$ & $\begin{array}{l}.089 \\
(.744)\end{array}$ & 1 & & & \\
\hline $\begin{array}{l}\text { Cardio vascular } \\
\text { disease }\end{array}$ & $\begin{array}{l}-.261 \\
(.328)\end{array}$ & $\begin{array}{l}-.122 \\
(.653)\end{array}$ & $\begin{array}{l}.320 \\
(.227)\end{array}$ & $\begin{array}{l}-.282 \\
(.291)\end{array}$ & $\begin{array}{l}-.182 \\
(.501)\end{array}$ & $\begin{array}{l}-.277 \\
(.298)\end{array}$ & $\begin{array}{l}.231 \\
(.298)\end{array}$ & $\begin{array}{l}-.488 \\
(.055)\end{array}$ & $\begin{array}{l}-.101 \\
(.710)\end{array}$ & 1 & & \\
\hline Osteoporosis & $\begin{array}{l}.141 \\
(.601)\end{array}$ & $\begin{array}{l}-.314 \\
(.237)\end{array}$ & $\begin{array}{l}-.289 \\
(.278)\end{array}$ & $\begin{array}{l}-.145 \\
(.592)\end{array}$ & $\begin{array}{l}.218 \\
(.417)\end{array}$ & $\begin{array}{l}.971 \\
(.097)\end{array}$ & $\begin{array}{l}.092 \\
(.733)\end{array}$ & $\begin{array}{l}-.169 \\
(.531)\end{array}$ & $\begin{array}{l}-.218 \\
(.417)\end{array}$ & $\begin{array}{l}.092 \\
(.733)\end{array}$ & 1 & \\
\hline $\begin{array}{l}\text { Gastro intestinal } \\
\text { disease }\end{array}$ & $\begin{array}{l}-.519 \\
(.040)\end{array}$ & $\begin{array}{l}.094 \\
(.729)\end{array}$ & $\begin{array}{l}.289 \\
(.278)\end{array}$ & $\begin{array}{l}.199 \\
(.459)\end{array}$ & $\begin{array}{l}-.218 \\
(.417)\end{array}$ & $\begin{array}{l}.333 \\
(.207)\end{array}$ & $\begin{array}{l}.092 \\
(.733)\end{array}$ & $\begin{array}{l}-.220 \\
(.413)\end{array}$ & $\begin{array}{l}-.218 \\
(.417)\end{array}$ & $\begin{array}{l}-.277 \\
(.298)\end{array}$ & $\begin{array}{l}.092 \\
(.733)\end{array}$ & 1 \\
\hline
\end{tabular}

*: 1. Amount of microorganism (pre), 2. Amount of microorganism (post), 3. Frequncy of toothbrushing, 4. Methods of toothbrushing, 5. Halitosis, 6. Gum pain, 7. Tooth pain, 8. Denture, 9. Hypertension, 10. Cardio vascular disease, 11. Osteoporosis, 12. Gastro intestinal disease

연령과 성별 등의 일반적 특성, 구강건강관리습관, 본인이 자각하는 구강건강상태 그리고 전신질환 보유 유무를 확 인하였다. 본 연구 대상자인 65 세 이상의 노인들에게 치 주병, 구취, 구강과 전신질환 관련성에 대한 이론지식, 칫 솔질 방법, 입체조, 틀니관리법에 대한 구강건강관리 교육 을 매주 1 회 총 4 회 시행하였고, 교육 전과 후의 타액을 각각 채취하여 타액 내 미생물의 총 양을 조사하였다. 타 액 내 미생물은 총 11 종을 확인하였으며 노인층에 유병 률이 높은 치주질환 위험 기여도에 따라 세 그룹으로 나 누어 분석하였다. Red complex에 해당하는 미생물 균주들 은 심각한 치주질환과 관련이 있으며, 치주낭 형성에 크 게 관여하는 것으로 알려져 있다(Rôças et al., 2001; Da silva-boghossian et al., 2011). 특히 Porphyromonas gingivalis는 치은연하 치면세균막에 존재하며 짧은 막대모양을 한 비 활동성, 완전혐기성, $\mathrm{G}(-)$ 단간균으로, 또한 급성 - 만성 치 주염과 관련성이 높고 독성이 높은 세균이다(Nishihara and Koseki, 2000). 이와 더불어 Aggregatibacter actinomycetem- comitans 균주는 red complex에 속하진 않지만 대표적인 급진성 치주질환 병인균으로 국소적으로 공격적이며 진행 속도가 빠른 것으로 알려져 있다(Stanley and Jeffrey, 2005). Orange complex에 해당하는 균주 그룹은 성인에서 발생 하는 치주염의 주요 병인으로 알려져 있다(Roberts et al., 2002). 본 연구에서 조사한 미생물 균주 중 Green complex 에 해당하는 것은 Eikenella corrodens 가 있으며, 이 그룹들 은 서로 상호작용하며 치주질환을 진행시키는 것으로 알 려져 있다(Carrouel et al., 2016). 따라서 본 연구에서는 구 강건강관리행태와 자각하는 구강상태, 전신질환 유무에 따른 설문조사를 시행하고 각 요인별로 교육 전, 후 미생 물 세 그룹의 총량이 유의하게 변화하는지를 확인하고자 하였다.

첫 번째 요인인 구강건강관리행태와 관련하여 설문한 내용은 칫솔질 방법, 칫솔질 횟수, 혀 닦기 유무에 대하여 조사하였으며 칫솔질을 회전법으로 시행한다는 응답군에 서 교육 전, 후 orange complex 미생물의 총량이 유의하게 
감소하는 것을 확인할 수 있었고, 1 일 칫솔질 횟수와 교 육 전, 후 미생물 총량의 감소와 관해서는 칫솔질을 3 차 례 하는 응답군과 혀를 닦는다는 응답군에서 교육 전, 후 Aa \& Red complex, orange complex 미생물 총량이 유의하게 감소되었다. 선행연구에 따르면 노인요양시설에서 근무하 는 요양보호사들을 대상으로 구강보건지식도와 구강보건 행태의 상관관계를 분석한 결과 양(+)의 관련성이 있다고 나타났다(Bae et al., 2014). 이러한 결과는 본 연구 대상자 가 기존에 보유하고 있던 구강건강관련지식이 높을수록, 구강건강에 대한 관심도가 높을수록 교육내용을 충실히 시행하여 효과가 있는 것으로 사료된다.

두 번째 요인인 구강상태에 따른 교육 전, 후 미생물 총량 감소효과를 확인한 결과, 의치를 장착하고 있다고 응 답한 군은 Aa \& Red complex에서 교육 전, 후 미생물이 유의하게 감소하는 것을 확인하였고, 의치를 장착하지 않 은 응답군은 세 그룹 모두에서 미생물이 유의하게 감소된 것을 확인할 수 있었다. 구취가 없다고 응답한 군에서도 Aa \& Red complex, orange complex에서 교육 전, 후 미생물 이 감소하는 것을 확인할 수 있었다. Lee (2016)의 의치장 착과 구취의 자가인지도에 관한 연구에 따르면 의치장착 그룹에서 구취가 난다는 자가인지 정도가 높았으며, 구강 건강지식이 높을수록 관심도가 높고 구강건강을 위한 행 동 실천율이 높아 실제 구취발생률은 낮다는 결과가 있었 다. 이러한 선행연구가 존재하지만 본 연구에서 확인된 결과는 선행연구와는 유사하게 도출된 결과가 없었으며, 의치장착 유무와 구취 유무와 관련하여 교육 전후 미생물 의 감소효과에 어떠한 의미를 부여하기에는 한계가 있는 것으로 사료되어 추후 부가적인 연구가 수행되어야 할 것 이다.

전신질환 유무와 교육 전, 후 미생물 총량 감소에 관하 여 조사한 결과, 고혈압이 있다고 응답한 군에서 $\mathrm{Aa} \&$ Red complex와 Orange complex의 미생물 총량이 교육 전 후 유의하게 감소하는 효과가 있었다. 또한 골다공증관련 질문에서는 없다고 응답한 군이 세 그룹 모두 유의한 감 소효과가 있었다. 위장장애관련 질문에서도 없다고 응답 한 군에서 Aa \& Red complex와 Orange complex의 유의한 감소효과가 있었다. 원(Won and Jin, 2003)에 의하면 전신건 강과 구강건강은 밀접한 관련이 있으며, 노인들은 체계적 인 구강보건교육이 필요하다고 하였다. 하 $(\mathrm{Ha}$ and Choi, 2013)의 연구에 따르면 본인이 자각하는 건강의 정도가 좋을수록 건강에 대한 관심도가 높고, 관심도가 높을수록 행위 실천 정도가 높은 것으로 사료된다고 하였으나, 본
연구에서는 건강에 대한 관심도를 결정지을 수 있는 요인 인 전신질환 보유 유무에 따른 교육 전, 후 미생물 감소효 과는 질병의 유무와는 무관하게 Aa \& Red complex, Orange complex의 미생물 총량이 감소하는 효과가 있었다.

본 연구에서 조사된 모든 변수간의 상관관계를 분석한 결과 구강건강관련 교육 전의 미생물 총량과 1 일 칫솔질 횟수, 위장장애 유무는 음의 상관관계를 가진다. 칫솔질 횟수가 많을수록, 위장장애를 보유한 사람일수록 교육 후 미생물의 총량이 감소하는 것이 본 연구에서 도출하고자 한 이상적인 결론이나 교육 전 미생물양과의 상관관계만 유의하다는 결과를 얻었다. 또한 잇몸통증과 고혈압이 유 의한 상관관계를 가지는 것으로 확인되었다. 이는 고혈압 이라는 질환이 잇몸통증을 더욱 상승시키는 데에 어떠한 관계가 있을 것이라는 것을 추측할 수 있다. 그러나 추후 보완 연구가 필요한 실정이다. 상관관계 분석 결과 본 연 구에서 사용한 요인간 교육 전, 후 효과에 대한 관련성 파 악은 어려운 것으로 사료된다.

본 연구에서 사용한 구취, 잇몸통증, 치아통증과 같은 변수는 객관적으로 진단된 것이 아닌 설문에 대한 대상자 의 응답에 의존한 점, 연구 대상자의 교육 전, 후 효과 비 교를 위해 변수를 제외한 다른 조건을 통제하지 못한 점 을 들 수 있으며, 표본 수가 16명으로 전체 노인을 대표하 기에는 힘들다는 한계점이 있다. 그러나 이 연구의 결과 는 칫솔질 방법, 빈도 등과 관련한 구강건강 관심도가 높 을수록 교육의 효과가 있었다는 것을 고려하여 제한적으 로 연구 결과를 받아들일 수 있을 것이다. 따라서 향후 변 수에 대한 객관적 정보를 보완하고 노인의 다양한 특성을 고려하여 체계적인 연구가 이루어져야 할 것이다. 그럼에 도 불구하고 노인의 주관적 구강건강관리행태와 구강건강 및 전신질환에 따른 구강보건교육의 효과를 분석하여 관 련성을 확인하였고 노인대상 구강건강증진을 위한 프로 그램 및 제도 개발에 기초자료를 제공했다는 데에 의의 를 둔다.

\section{ACKNOWLEDGEMENT}

This work was supported by the National Research Foundation of Korea (NRF) grant funded by the Korea government (MSIT) (NRF-2017R1C1B5076722).

\section{CONFLICT OF INTEREST}

No potential conflict of interest relevant to this article was reported. 


\section{REFERENCES}

Bae SS, Moon HY, Moon YM. Study on the Oral Health Behaviors of Geriatric Care Helpers. Journal of the Korea Entertainment Industry Association. 2014. 8: 199-206.

Carrouel F, Viennot S, Santamaria J, Veber P, Bourgeois D. Quantitative Molecular Detection of 19 Major Pathogens in the Interdental Biofilm of Periodontally Healthy Young Adults. Front Microbiol. 2016. 7: 840.

Choi ES, Cho HA. Association between Oral Health Status and Rheumatoid Arthritis. J Dent Hyg Sci. 2015. 15: 612-619.

Cho YY. Relationship between the number of remaining teeth and bone health status among the elderly in Korea. J Korean Soc Dent Hyg. 2018.18: 205-215.

Da silva-boghossian CM, Do souto RM, Luiz RR, Colombo AP. Association of red complex, A. actinomycetemcomitans and non-oral bacteria with periodontal diseases. Arch Oral Biol. 2011. 56: 899-906.

Ha JY, Choi EY. Health Perception, Health Concern, and Health Promotion Behavior of the Elders. J Korean Gerontol Nurs. 2013. 15: 277-285.

Joung SA, Cho EA. Effects of Normal Saline Solution Mouthwash on Oral Health Status, Xerostomia, Halitosis and Salivary pH in Elders in Long-term Care Facilities. J Korean Gerontol Nurs. 2017. 19: 173-183.

Lee KH. A Study on the Relationship Between Halitosis and Dentures. Sci Emot Sensib. 2016. 19: 127-136.

Lee JY, Lee SM, Lee HW. Porphyromonas gingivalis Invasion of Human Aortic Smooth Muscle Cells. International Journal of Oral Biology. 2008. 33: 163-177.

Lim MY, Kim HS, Jeong JH, Yang JY, Oh SH, Kook JK. Detection rate of periodontopathogens associated with cardiovascular disease in denture. The Korean Journal of Microbiology. 2004. 40: 273-243.

Meyerowitz C. Geriatric dentistry and prevention: research and public policy (reaction paper). Advances in Dental Research 1991. 5: 74.
Nishihara T, Koseki T. Microbial etiology of periodontitis. Periodontolo 2000. 2004. 36: 14-26.

Park SM. Effects of Health Status on Life-Satisfaction of the Elderly: Focusing on the mediating and moderating effects of social activities. Journal of Welfare for the Aged. 2011. 53: 305-332.

Roberts A1, Matthews JB, Socransky SS, Freestone PP, Williams $\mathrm{PH}$, Chapple IL. Stress and the periodontal diseases: effects of catecholamines on the growth of periodontal bacteria in vitro. Oral Microbiol Immunol. 2002. 17: 296-303.

Rôças IN, Siqueira JF Jr, Santos KR, Coelho AM. "Red complex" (Bacteroides forsythus, Porphyromonas gingivalis, and Treponema denticola) in endodontic infections: a molecular approach. Oral Surg Oral Med Oral Pathol Oral Radiol Endod. 2001. 91: 468-471.

Roh JY, Kim KR. Antimicrobial activity of Korean propolis extracts on oral pathogenic microorganisms. J Dent Hyg Sci. 2018. 18: 18-23.

Socransky S, Haffajee A, Cugini M, Smith C, Kent R. Microbial complexes in subgingival plaque. J Chin Peridontol. 1998. 25: 134-144.

Stanley CH, Jeffrey LE. Porphyromonas gingivalis, Treponema denticola, and Tannerella forsythia: the 'red complex', a prototype polybacterial pathogenic consortium in periodontitis. Periodontology. 2000. 38: 72-122.

Won YS, Jin KN. The relationship of oral state and health condition among elderly people. J Korean Acad Dental Hygiene Education. 2003. 3: 157-168.

Yang SB, Moon HS, Han DH, Lee HY, Chung MK. Oral heatlh status and treatment need of institutionalized elderly patients. J Kor Acad Prosthodont. 2008. 46: 455-469.

https://doi.org/10.15616/BSL.2018.24.4.372

Cite this article as: Lee MK, Yu SB, Kim HJ. Analysis of Oral Pathogenic Microorganisms by Elderly's Systemic and Oral Health Status of the Elderly Over 65 Years. Biomedical Science Letters. 2018. 24: 372-379. 